\title{
Introduction: Antonio Gramsci and Educational Thought
}

\section{Peter Mayo}

I write this Introduction at a time when several organizations throughout the world are winding up or have just wound up their series of activities commemorating the $70^{\text {th }}$ anniversary of the demise of Antonio Gramsci. Gramsci has been granted iconic status in many countries, where every tenth anniversary of his death does not pass unnoticed, given the several activities and seminars held in his honour. Gramsci enjoys one of the widest influences in social theory, except perhaps in his own country where he represents a classic case of nemo profeta in patria. Of course one comes across the usual activities carried out by the Fondazione Istituto Gramsci, including a two-day conference in Rome in April 2007, which drew scholars from different parts of the world. The local council (Comune) in his home town of Ghilarza understandably also carried out a series of activities to mark the anniversary year. This notwithstanding, one gathers the impression that Gramsci is much more revered outside Italy - in Germany, France, Canada, the USA, the United Kingdom, Finland, South Africa, India and Latin America, for example-than within his homeland. His image in Italy seems to have suffered following the fall of the Berlin Wall and the transmutations that occurred within the former Italian Communist Party Gramsci helped found in 1921.

This book, however, seeks to pay tribute to this great political figure and social thinker of the $20^{\text {th }}$ century. It comprises chapters from different parts of the world including New Zealand, Brazil, the United States, Canada, Germany and England. It complements another publication which I co-edited (Borg et al., 2002) in that it draws on the work of authors with which we three editors of the 2002 book were not familiar at the time of planning that volume. I was very careful therefore not to include in this book authors who had contributed to the 2002 book. The issues tackled are various. Deb Hill provides an in-depth philosophical discussion on the Hegelian and Marxian influence on Gramsci's 'philosophy of praxis' arguably the central phrase in his prison writings originally intended as a work 'für ewwig' (for eternity). The connections between Gramsci's thought and Marx's theory of consciousness and dialectical mode of thinking are carefully teased out here. This piece complements the work of Paula Allman (2002) around the subject.

Gramsci's entire project in the prison writings, centring on the notion of hegemony, of which he does not provide a systematic exposition, is an educational projecteducation in the broadest sense possible. Education is central to the workings of hegemony in which every relationship is a pedagogical relationship. In other words, 
to do justice to Gramsci's writings that are of relevance to education, one should tackle Gramsci's work holistically (Borg et al., 2002) and not confine oneself to the tract on schooling, or more precisely 'the Unitarian school', found in Notebook 4 and revised in Notebook 12. Gramsci's pre-prison writings are also of great relevance here, together with some of his letters, since Gramsci accorded different forms of education, including adult education, great importance, considering their organization to be a key task of the Modern Prince that is the revolutionary party. This constitutes the subject of a well-informed chapter by John Holst, an attempt to see the several 'altre vie', which Gramsci explored for education, within the context of party work. As Holst underlines (see also Holst, 2001), it is fashionable these days to dilute or camouflage this aspect of Gramsci's thinking to render his ideas suitable for contemporary and possibly liberal appropriation.

And yet despite the wide range of educational activities which Gramsci explored both outside and inside prisons (recall his contributions to the development of the Scuola dei Confinati-prison school-at Ustica when awaiting trial, the Club di Vita Morale, the Institute of Proletarian Culture inspired by the Proletkult and the correspondence party school) quite an interesting debate arose, in the educational literature of the late 1970s and 1980s, around his notes on the Unitarian School. This was mainly because of the publication of Harold Entwistle's (1979) wellresearched book (covering most aspects of education tackled by Gramsci) with its provocative title Antonio Gramsci. Conservative schooling for radical politics. This book sparked off quite a debate around Gramsci's conception of schooling in reaction to the Riforma Gentile. For this reason we are including, in this volume, a highly informative piece by Thomas Clayton, concerning Gramsci and the actual pedagogical ideas of Giovanni Gentile, the leading Italian idealist philosopher who, together with Benedetto Croce, is widely regarded in Italy as having kept Italian philosophy rooted in idealism (some argue derogatorily that he rendered Italian philosophy quite 'provincial' in this respect) through which it therefore developed a strong anti-positivist stance. Gentile, of course, became Italy's Minister of Education (Pubblica Istruzione) during the Fascist period and, as the title 'Riforma Gentile'(the Gentile Reform) indicates, was responsible for the scholastic reform that Gramsci criticised. Clayton (2006), the editor of a very revealing volume on some international reinventions of Gramsci's ideas, seeks to 'do justice' to Gentile in this well researched piece.

It would be amiss to discuss Gramsci's political and educational ideas without giving due consideration to one of the major preoccupations in his thinking, and the area of his specialization (indirizzo) at the University of Turin: language. Gramsci's writings on language have been the concern of several leading Italian scholars including Tulio de Mauro (the great linguist who served as Minister of Education in Italy in the Amato Government). Peter Ives is arguably one of the leading contemporary writers on Gramsci's notion of Language and Hegemony as testified by his two books on the subject (Ives, 2004a,b). I am pleased therefore to be able to include a contribution from him with respect to the Hegemony of Global English. For the concept of hegemony, as Ives has been at pains to indicate, featured prominently in the linguistics debate to which the young Gramsci was 
exposed at the University of Turin as a student of the acclaimed Matteo Bartoli who once hailed the young Sardinian as the archangel destined to defeat the grammarians.

Gramsci's influence is however felt in a variety of areas, including feminism (see Holub, 1992) and community development (see Ledwith, 2005). Margaret Ledwith provides us with a Gramscian analysis of community development from a feminist perspective drawing on her own work as a practitioner in the field. Furthermore we notice the various discussions in the educational literature on the relevance of Gramsci's thought for different aspects of education in specific continents or countries. Uwe Hirschfeld from Dresden is, together with Ursula Apitzsch, Armin Bernhard and Andreas Merkens, among the most prominent German scholars writing on Gramsci and education, working collaboratively with one of the major German publishing houses that promote Gramsci's work: Argument Verlag. Hirschfeld provides us with an interesting discussion, translated from the original piece in German, concerning Gramsci's relevance for social pedagogy, an important area of educational, social and cultural work throughout Germany. Furthermore, as indicated earlier on and in other volumes, Gramsci has a major following in Latin America especially, as indicated by Morrow and Torres (1995), in the field of popular education. He is also influential in the debates about schooling and Carlos Nelson Coutinho (1995), one of the leading Brazilian Gramscian scholars, states that he has been very influential in the work of Brazil's ruling Partido dos Trabalhadores (at least in its early years). Rosemary Dore Soares (2000), who authored a book on the subject of Gramsci, the State and Brazilian education, provides us with a very revealing and insightful piece on the subject.

The range of subjects tackled and the international representation found in this book make for a very variegated and rich compendium of writings on Gramsci's relevance to educational thought. It should make a strong contribution to the ever growing international literature on Gramsci and education.

\section{References}

Allman, P. (2002) Antonio Gramsci's Contribution to Radical Adult Education, in: C. Borg, J. A. Buttigieg \& P. Mayo (eds), Gramsci and Education (Baltimore, MD, Rowman \& Littlefield).

Borg, C., Buttigieg, J. A. \& Mayo, P. (2002) Introduction. Gramsci and Education. A holistic approach, in: C. Borg, J. A. Buttigieg \& P. Mayo (eds), Gramsci and Education (Baltimore, MD, Rowman \& Littlefield).

Clayton, T. (ed.) (2006) Rethinking Hegemony (Melbourne, James Nicholas Publishers).

Coutinho, C. N. (1995) In Brasile, in: E. J. Hobsbawm (ed.), Gramsci in Europa e in America (Italian edition edited by A. Santucci) (Roma-Bari, Sagittari Laterza).

Dore Soares, R. (2000) Gramsci, o Estado e a Escola (Ijui, Rio Grande do Sul, Editora Unijui).

Entwistle, H. (1979) Antonio Gramsci. Conservative schooling for radical politics (London and New York, RKP).

Holst, J. (2001) Social Movements, Civil Society, and Radical Adult Education (Westport, CT and London, Bergin \& Garvey).

Holub, R. (1992) Antonio Gramsci. Beyond Marxism and Postmodernism (London and New York, Routledge). 
Ives, P. (2004a) Gramsci's Politics of Language. Engaging the Bakhtin Circle and the Frankfurt School (Toronto, University of Toronto Press).

Ives, P. (2004b) Language and Hegemony in Gramsci (London/Halifax, Pluto/Fernwood).

Ledwith, M. (2005) Community Development. A Critical Approach (Bristol, Policy Press).

Morrow, R. A. \& Torres, C. A. (1995) Social Theory and Education. A critique of theories of social and cultural reproduction (Albany, SUNY Press). 